\title{
Guerrilheiros ou sacerdotes? Professores de História, consciência histórica e construção de identidades
}

Caroline Pacievitch ${ }^{*}$ e Luis Fernando Cerri ${ }^{* *}$

Resumo: A preparação específica para trabalhar profissionalmente com a História tem quais efeitos sobre a consciência histórica do professor? Este artigo apresenta os resultados de pesquisa de Mestrado em Educação realizada entre 2005 e 2007. Investigou-se a constituição de identidades de professores de História a partir do eixo da formação de consciência histórica, tendo como pilares de análise a relação com o conhecimento histórico, com o posicionamento político e com a relação com o transcendental (religiosidade). A fundamentação teórica repousa principalmente nos trabalhos de Rüsen e Heller. A metodologia incluiu a coleta de depoimentos, visando a produção de narrativas específicas e questionários abertos e de múltipla escolha. Os resultados apontam, entre outros aspectos, que a formação em História conduz a um padrão de produção de sentido histórico concentrado nas formas genética e crítica, mas também que a trajetória de vida é o principal fator de variação individual nesses padrões.

Palavras-chave: formação de professores; consciência histórica; memória; depoimentos orais.

\section{Guerilla soldiers or priests? History teachers, historical consciousness and identity building}

Abstract: What are the effects of a teacher's specific preparation for professionally working with history on his/her historical consciousness? This paper presents the results of research developed at the Pos-Graduation Program in Education, between 2005 and 2007. The constitution of history teachers' identities was investigated from the axle of historical consciousness building. The basis for investigation was the relationship with historical knowledge, with political stands and with religiousness. The theoretical foundations were drawn from the works of Rüsen and Heller. The methodology involved the collection of oral or written depositions aiming at the production of specific narratives destined to survey historical consciousness characteristics, as well as open and multiple-choice questionnaires. The results indicate that, among other data, education in history leads to historical meaning production patterns concentrated on the genetic and critical modes, but also that a subject's life story is the main individual variation factor for those patterns.

Key words: teachers' education; historical consciousness; memory; oral depositions.

* Doutoranda em Educação, Faculdade de Educação, Unicamp, Campinas, SP, Brasil. Bolsista Capes.pacievitch@gmail.com.

* Professor do Departamento de História e do Programa de Pós-Graduação em Educação, Universidade Estadual de Ponta Grossa, PR, Brasil. Ifcerri@uepg.br 
A vivência como docentes na educação básica sempre foi fonte de tensão e dificuldade de articulação entre os ideais teóricos e metodológicos estabelecidos na graduação e a realidade do ensino. Entre os estereótipos do revolucionário e do abnegado, fica a sensação de que ser professor de História é algo especial, diferente, e as vivências pessoais deixaram isso cada vez mais claro. A configuração da problemática desta pesquisa passa pelas discussões sobre a relação entre a consciência histórica e a Didática da História. A ligação entre as teorias referentes à consciência histórica e as interrogaçōes sobre o que vem a ser e como se faz cotidianamente a identidade do professor de História firmouse ao reconhecermos, com Rüsen (2001) e Heller (1993), que a principal forma de expressão da consciência histórica é a narrativa. Em leituras anteriores, ainda, consolidou-se a convicção de que é imprescindível fazer pesquisa sobre profissionais da educação, ouvindo-os adequadamente (Goodson, 1995). Principalmente neste caso, que envolve problemas da constituição de identidades e das formas pelas quais os professores compreendem o conhecimento acadêmico e lhe atribuem sentido. Isso se reflete na realização das aulas, na compreensão de seu papel político como professores e cidadãos, na relação com a afetividade e a religiosidade na profissão e na vida em geral.

Os objetivos da pesquisa materializam-se no exercício de verificar até que ponto a teoria da consciência histórica, conforme exposta por Jörn Rüsen, é capaz de lançar luzes na investigação de falas de professores de História referentes às identidades históricas. Daí a contribuiçãa de Agnes Heller, ao enfatizar a "Responsabilidade Planetária" como a finalidade maior e a expressão de um dos principais estágios da consciência histórica na atualidade. Por isso, tenta-se verificar como (ou se) os professores se identificam com os estereótipos, como criam formas de conviver com as exigências sociais, políticas, emocionais e pessoais do ser professor de História.

Ser professor é, entre outras coisas, ter de tomar decisões. Neste processo, a consciência histórica realiza um papel fundamental, pois permite localizar os problemas no tempo, pensar possíveis soluções, adequar mudanças às identidades temporais já existentes, modificá-las, se necessário. Portanto, em primeiro lugar, neste artigo, discutem-se as concepções de consciência histórica e as identidades adotadas.

\section{Sobre consciência histórica e identidades}

Rüsen (2001, p. 57) define consciência histórica da seguinte forma:

A suma das operaçôes mentais com as quais os homens interpretam sua experiência da evolução temporal de seu mundo e de si mesmos, de forma tal que possam orientar, intencionalmente, 
sua vida prática no tempo [...], o modo pelo qual a relação dinâmica entre experiência do tempo e intenção no tempo se realiza no processo da vida humana.

Ele complementa que todo ser humano, mesmo o homem "comum e cotidiano", tem necessidade de equilibrar-se entre suas intencionalidades e as contingências e as mudanças do tempo. O eixo da argumentação de Rüsen está na crença de que existe um pensamento histórico genérico, com características e estruturas próprias, e que é a partir dele que se desdobram formas específicas da História: consciência histórica, História científica e produções de cunho historiográfico veiculadas na mídia, por exemplo.

Agnes Heller (1993) tem uma concepção semelhante, ao apoiar suas consideraçôes sobre a teoria da História no papel estruturador que têm os fatos cotidianos, como o contar histórias, a curiosidade sobre os muitos passados e sobre o que "verdadeiramente aconteceu". Para Heller (1993, p. 15), a consciência histórica configura-se em diferentes possibilidades de respostas para a mesma pergunta fundamental - "Quem somos, de onde viemos e para onde vamos?" - ou seja, a pergunta identitária básica, que engloba a necessidade de conhecimento de histórias (que podem aparecer em forma de mito, de memória, de ciência...) e de manutenção e transformação de identidades.

Ambos os autores estabeleceram classificaçōes para diferentes níveis ou formas de consciência histórica. Optamos por trabalhar com as categorias de Rüsen, por serem as mais diretamente adequadas à problemática. ${ }^{1}$

As formas de geração de sentido não devem ser entendidas como fases obrigatórias e hierarquicamente organizadas. Um mesmo indivíduo pode demonstrar tipos diferentes, depende da situação em que se encontra, da necessidade de gerar sentido. O fenômeno da consciência histórica é, portanto, um processo mental individual, obviamente não desconectado do coletivo e contingente. Por isso, as perguntas sobre as identidades de professores de História não se formulam sem recorrer a representaçōes coletivas sobre a profissão (na forma de pressōes sociais, em geral, ou na forma de pressões oficiais).

Todos buscam sentido entre o tempo que escapa ao controle (as contingências) e o tempo que está "humanizado" (a cronologia, aquele tempo sobre o qual existe algum tipo de poder). Ninguém se satisfaz com o tempo que vai do próprio nascimento até a morte, precisa conhecer o passado (posto que imersos num mundo que já existia antes). A projeção de um futuro também é regra

1. As quatro formas de geração de sentido em Rüsen foram sintetizadas no quadro disponível no texto de Rüsen intitulado "Historical consciousness: narrative structure, moral function and ontogenetic development" (In: Seixas, 2004). 
geral: para todos existe um amanhã para o qual se fazem planos e se estabelecem projetos de ação (Rüsen, 2001).

Assim, reitera-se que a vida cotidiana apresenta desafios temporais e identitários para os professores, sendo necessário lançar mão dos processos de consciência histórica, a fim de interpretar seu tempo, criar estratégias de ação e manter ou modificar suas identidades. Isso se assemelha às ideias de Conjuntividade e Pessoalidade em Heller: só se vive em função de tempos que ultrapassam o que é exclusivamente individual, por isso o destaque ao tempo do "Agora”. É um estado de tensão entre o que "já foi" e o "que ainda não é". Elementos de orientação tornam-se necessidades básicas; estabelecer sentido ao tempo é pré-requisito para agir sobre ele, para tomar decisões de cunho moral, para preservar ou adaptar identidades. Esse processo depende do elemento experiencial, que pode vir através da memória, da historiografia ou das mais diversas formas de conhecimento histórico em geral (filmes, canções, histórias dos antepassados, etc.). Lembranças e memórias devem estar articuladas de forma que estabeleçam uma relação de continuidade entre a carência provocada pelo presente, pelo passado e pelas expectativas de futuro. Ainda, é preciso que essa continuidade tenha como eixo as identidades daquele que pretende produzir sentido ao tempo. Esses elementos organizam-se e expressam-se na forma de narrativa histórica, que inclui operações emocionais e cognitivas, conscientes e inconscientes (Rüsen, 2001).

Nos textos de Heller, fica claro que a narrativa histórica se constrói a partir dos grupos que se interessam por elas; portanto, narrativas históricas podem ser momentos de afirmação ou desconstrução de identidades. Ao mesmo tempo que as narrativas históricas permitem os trabalhos das identidades e atribuições de sentido, também as histórias são modificadas a partir das identidades e das necessidades dos grupos ou indivíduos.

Para identificar a narrativa histórica, Rüsen (2001) estabelece alguns critérios: 1) forma: ela deve possuir a estrutura de uma história (a interpretação e o significado das três dimensōes temporais); 2) conteúdo: precisa incluir a experiência de passado (memória e demais conteúdos de conhecimento histórico); 3) função: deve contribuir para a orientação da vida humana prática, para tomadas de decisão e legitimação destas; e 4) motivação para o agir (o que não significa, necessariamente, que a ação seja reflexo exato do pensamento). $\mathrm{Na}$ teoria, são esses os quatro elementos que, articulados, permitem que o homem possa estabelecer sentido à sua relação consigo e com o mundo a partir da passagem do tempo.

Atribuir sentido é, portanto, a tarefa básica da consciência histórica, que orienta as açôes humanas no tempo. A ampliação que Heller (1992) confere ao conceito é valiosa. Segundo ela, é imperativo fazer do cotidiano um conjunto 
de ações morais e políticas, evitando a mera reprodução de papéis. É o sentido de "Responsabilidade Planetária" (1993) ou "autodeterminação coletiva" (1998) que inclui nos resultados da consciência histórica o enfrentamento do niilismo e do desespero através de atividades de transformação consciente de tudo o que causa sofrimento aos seres humanos. Ao que tudo indica, o que os professores consideram como suas ações políticas aproxima-se desse conceito.

A identidade como fator de desorientação mostra-se inclusive pelas características da sociedade de consumo: as pessoas não são preparadas para adiar suas necessidades, mas para satisfazê-las o mais breve possível, criando novas necessidades. E isso, obviamente, leva à tendência de trocar de lugar, ou de comunidade, sempre que se crie uma nova situação. $\mathrm{E}$ a angústia encontra-se aí: que comunidade, ou que identidade escolher e quanto tempo permanecer ligado a ela? (Bauman, 2005).

Pode-se imaginar que Rüsen (1992) atribui à consciência histórica uma função extremamente difícil: manter identidades produzidas ou, então, ajudar a escolher uma comunidade que esteja adequada ao seu contexto e às suas necessidades. Pode-se questionar se esse processo irá aparecer tão problemático para todos os sujeitos da pesquisa ou se as estratégias utilizadas para enfrentar os trabalhos das identidades podem ser mais, ou menos, eficientes contra a angústia e a indecisão.

As ideias de Bauman cruzam-se com as de Agnes Heller através do conceito de Responsabilidade Planetária. O trabalho da consciência histórica, ao mobilizar memórias e conhecimentos a partir de um interrogante do presente procura atribuir sentido ao problema vivido, inserindo-o numa trajetória temporal significante. Como resultado desse processo mental cotidiano, um repensar, realocar ou reafirmar das identidades que não encontra fronteiras definidas. No presente estudo, o conhecimento histórico, a visão política e o sentimento religioso envolvem-se em teias diferenciadas, dependendo da situação e da história de cada professor.

\section{Caminhos}

Diversas obras auxiliaram na construção metodológica, destacando-se os clássicos referentes ao uso de fontes orais, como Portelli e Meihy (1997, 1996). As teorias sobre consciência histórica não trazem ainda referenciais metodológicos próprios. Ainda assim, existem várias pesquisas sobre consciência histórica em busca da construção de caminhos de investigaçãa ${ }^{2}$. Para os objetivos ora pro-

2. Vejam-se, por exemplo, Künzle (2003), Kusnick (2008), Angvik e Borries (1997), Schmidt e Garcia (2005). 
postos, a coleta de narrativas foi imprescindível, e a obra de Selva G. Fonseca (2003) foi uma referência central, por desenvolver de modo específico o processo de coleta e análise de depoimentos de professores de História.

Muitos são os exemplos de trabalhos que aproveitam narrativas de professores, e abundam as nomenclaturas, mas os usos são semelhantes. No presente caso, para controle dos resultados, adaptou-se a criação dos roteiros e dos questionários a partir das características da narrativa histórica (Rüsen, 2001), combinando respostas a um questionário fechado com a captação das formas de atribuição de sentido à mudança temporal, cruzando-as com uma massa maior de dados. Por isso, criaram-se estratégias metodológicas que permitissem observar as várias frentes propostas pelas características da narrativa histórica: a atribuição de sentido e significado, as memórias e os conhecimentos históricos, as funçōes de orientação e motivação, os problemas propostos pela vida prática, as utopias.

Levaram-se em consideração as quatro formas de atribuição de sentido (tradicional, exemplar, crítica e genética), cujo potencial heurístico se pretendia testar, tendo como acessório a concepção de consciência histórica proposta por Heller (1993).

Com o auxílio de M. Huberman (1995), foram estabelecidos os perfis típicos para a escolha dos profissionais entrevistados, a partir do estágio da carreira: professores recém-formados, em meio de carreira, com cerca de 20 anos de profissão, e os aposentados. Como complemento, cruzaram-se esses itens com características de filiação político-partidária, social, religiosa, ambiental, etc. e o fato de serem ou não habitantes da região dos Campos Gerais. A maior titulação deveria ser Mestre.

Para entrevistar professores de outros Estados, recorreu-se aos contatos virtuais. Em comunidades e grupos de discussão da Internet, foram encontrados professores que demonstraram, de alguma forma, interesse pelos temas das identidades de professores de História e da consciência histórica.

A coleta de dados dividiu-se em duas fases. Na primeira, foram entrevistados cinco professores, que responderam a um questionário simples, responsável por captar dados factuais sobre a trajetória de vida e formação. Em seguida, gravou-se entrevista a partir de um roteiro básico que solicita informaçôes sobre histórico familiar e escolar, memórias do período de formação, conceituaçôes a respeito da História e do saber histórico e vida profissional. As entrevistas foram transcritas e passaram pela aprovação dos professores.

O terceiro questionário foi responsável por oferecer balizas concretas para a identificação da forma de geração de sentido histórico da qual cada professor se aproxima. Consta de três pequenas narrativas que implicam tomada de decisão por parte do professor. Para respondê-lo, há quatro alternativas, cada uma refe- 
rente a um dos níveis de consciência histórica propostos por Rüsen (2004), além da possibilidade de escrever uma quinta resposta. As três narrativas dizem respeito, respectivamente, a formas de mobilização política, às relaçôes entre ciência histórica e religião e a tradiçōes familiares e sociais. Esses temas foram escolhidos, tendo em vista o caráter orientador da consciência histórica sobre as decisões de cunho moral, político e da vida cotidiana e também por serem passíveis de relacionar-se com os perfis delineados para a seleção dos entrevistados.

Para a segunda fase, elaborou-se novo questionário com base nos principais pontos surgidos dos depoimentos anteriores: relacionamento com o conhecimento histórico, postura política e religiosidade. Esse questionário possui 5 perguntas ( 3 abertas e 2 fechadas) e foi aplicado aos professores de História de todas as escolas da zona urbana do município de Ponta Grossa, totalizando 67 respostas, nos meses de outubro, novembro e dezembro de 2006.

As análises obedeceram a três momentos. O primeiro chamou-se "análise vertical", quando os depoimentos dos cinco primeiros professores foram discutidos a partir de suas características internas e em relação com a teoria. Em seguida, os dados dos 67 questionários foram tabulados, formando-se gráficos, e foram analisados de forma individual. Por fim, o terceiro momento, quando todo o corpo de dados foi cruzado para a obtenção das conclusóes parciais e para a verificação dos objetivos propostos, que serão apresentados na última seção deste artigo.

\section{Conte-me sua história}

Nesta seção, apresentam-se as narrativas dos cinco professores entrevistados na primeira fase. Inicialmente descreve-se parte das histórias de vida de cada professor. Em seguida, alguns tópicos de análise são discutidos: formas de geração de sentido utilizadas na concepção de saber histórico, ideias políticas e vivências religiosas. Essas foram algumas das principais recorrências encontradas nas narrativas dos professores, que revelam a diversidade de períodos de vida profissional e pessoal, vinculações políticas e religiosas, local de atividade, etc., conforme proposto na seção metodológica. Os nomes são fictícios e inspirados em elementos da biografia de cada um. Os trechos em itálico correspondem a citações diretas das entrevistas.

\section{Ernesto}

Jovem e quase sem experiência concreta como professor, Ernesto viveu desde os 12 anos com uma tia que poderia dar-lhe melhores condiçôes de estudo. 
Sua vida escolar oscilava entre o interesse pelo conhecimento e as atitudes de um "verdadeiro demônio", que o levavam com frequência à sala da diretoria. Lá, conviveu com outro lado do mundo dos professores, o que, em parte, além da influência de professores, o fez optar pela educação. Sair de casa para frequentar o curso de História e participar do movimento estudantil fez com que "perdesse um pouco da inocência" e colaborou para o posicionamento político segundo ele - mais à esquerda.

$\mathrm{Na}$ maior parte de suas respostas, demonstra a influência que os estudos acadêmicos têm sobre as decisōes e os julgamentos. Ele tenta, constantemente, relacionar a teoria aprendida com a prática política e de sala de aula, que pensa não estarem desvinculadas.

Ernesto tem clareza de que está envolto numa dada Conjuntividade, principalmente pela forma tranquila como se localiza como "Pessoalidade": os tempos (a liberdade e o contingente) estão em suas mãos, agora é necessário agir. Agir como cidadão e como professor de História, evitando permanecer na passiva compreensão do mundo, mobilizando-se em favor daquilo que acredita ser o melhor para a escola, para a classe docente e para a sociedade em geral. $\mathrm{O}$ papel do professor, aqui, é eminentemente político - embora não proselitista.

Evidente que sua preocupação não está centrada na mera satisfação de carências, posto que sente muito mais a desqualificação social em relação à profissão (manifesta nos "sorrisos amarelos") do que a econômica. Tem-se a impressão de que a criação da sua identidade como professor de História entrelaçou o "desejo" de ser professor, o "gosto" pela História e os múltiplos conhecimentos adquiridos durante a graduação sobre educação, História, sociedade e política, principalmente.

André

André fala pouco sobre a vida pessoal e seu passado. Não responde às questóes referentes ao significado de processo histórico e saber histórico. Revela que suas leituras favoritas estão fora do mundo acadêmico, tendo em vista que este não tem relação alguma com as dificuldades enfrentadas em sala de aula. É Mestre em História, já foi aprovado para doutorado, mas não freqüenta, por falta de bolsa de estudos. Também já pensou em abandonar a profissão, o que não faz porque "gosta" de ser professor.

Para André, o fato histórico mais interessante foi a Ditadura Militar. Ele também cita que, quando ensina o Bloqueio Continental de Napoleão Bonaparte, sempre o relaciona às ligações dos Estados Unidos com Cuba e com o Oriente Médio. Segundo ele, dessa maneira "fica mais agradável e fácil do aluno compreender". Porém, insiste-se que ele dê um exemplo em sua vida prá- 
tica e, depois de alguma hesitação, André responde: "As cruzadas, uma 'guerra santa' do periodo medieval, e os atentados com homens bomba no mundo hoje".

Novamente, há pouca implicação de si próprio nas respostas, mas André é claro no que diz respeito à importância do que ensina. É assim que compreende o papel do professor de História, longe dos ditos acadêmicos e dos estereótipos a respeito do professor de História, pois, por mais que se diga punk, André não deixa de atribuir uma importante função social para o professor de História, ao tentar mobilizar o pensamento de seus alunos.

Sofia

Sofia é uma professora aposentada de História, mas ainda em atividade. Ela utiliza muitos dos termos e das reflexôes filosóficas para elaborar suas respostas, inclusive em sua inserção na chamada "Responsabilidade Planetária". Trabalhou tanto em escolas particulares quanto públicas, no ensino básico e no superior, tendo, inclusive, publicado um livro sobre Imigração. Atualmente, leciona Realidade Brasileira no seminário católico da cidade.

Sofia é sucinta e evita dar exemplos pessoais. Professa a religião católica. É filiada ao sindicato, mas não participa das mobilizações. Não diz ter passado por crises profissionais/identitárias sérias e revela que, apesar de não oficialmente vinculada a nenhum tipo de movimento, comunga, conscientemente, valores e ideologias com alguns deles, principalmente de cunho religioso e de assistência social.

Indagada sobre o momento histórico que a marcou, Sofia responde:

A bomba atômica. Acho que a maior idiotice da história da humanidade. E aí você pode até dizer "está negando o progresso". Mas eu até gostaria de negar o progresso uma vez que nesse sentido a utilização da energia nuclear foi altamente negativa, danosa pra toda a humanidade.

A citação da bomba atômica aparece como uma história ultracurta (Rüsen, 2004) que orienta suas ideias sobre "consciência de humanidade" e sobre o papel do professor de História. Outro momento citado foi a Ditadura Militar, não pelo que ela viveu na época, mas pelo fato de que as violaçóes dos direitos humanos passaram totalmente despercebidas quando ocorreram, gerando um choque quando chegaram ao conhecimento público.

Nota-se que, apesar de sermos "todos políticos" e responsáveis uns pelos outros, há momentos em que simplesmente "não sabemos o que se passa" e não é possível fazer nada. Daí o papel da História: trazer conhecimento a ser refletido. Segundo a professora, ao estudar a Ditadura e a resistência, é possível concluir que o brasileiro não é um povo "pacato", mas que deveria estar lutando 
contra os fatos "terriveis" que vêm acontecendo na política atual. Sem dúvida, o sentido atribuído à história, aqui, é exemplar, com a pretensão de motivar os jovens para açôes e transformaçôes, pois entender a conjuntura é fundamental para a atuação cidadã hoje.

Em Sofia, é possível verificar a existência de uma consciência histórica preocupada em construir um futuro - uma utopia - a partir da ideia de Conjuntividade, que implica a interpretação do passado como um "passadopresente", a partir dos valores que a Responsabilidade Planetária impõe: "eu tenho certeza de que eu fiz o possivel, dentro das minhas possibilidades.".

Olga

Olga é uma professora em meio de carreira, viúva, altamente ligada a movimentos políticos e sociais de esquerda, ONGs de preservação ambiental e Pastorais. Quando trabalhava dando aulas de inglês em escola próxima a uma reserva indígena e a um assentamento, conheceu o líder do assentamento, passou a refletir com ele sobre a situação e, aos poucos, assumia aulas de História e abandonava as de inglês. Eles se casaram e ela iniciou a graduação em História. No meio do curso, seu marido faleceu de maneira que até hoje não foi bem explicada para ela. Assim, inúmeras "carências de orientação" formaram-se, e ela tentou buscar na História o sentido que precisava.

Frequentemente, sua vida profissional é colocada em questão pelas incoerências entre o que ela acredita e o que deve fazer na escola.

Assim como André, ela recusa parte da literatura acadêmica para ensinar História, visto que tais obras ignoram as mulheres, o Oriente e os próprios adolescentes. Se não tivesse as vivências em movimentos e partidos, não seria uma professora tão comprometida com os caminhos e as utopias que seus alunos precisam encontrar. Para ela, a História "te dá caminhos, não te dá resposta [...]. E eu acabei descobrindo que a História me abriu muitos caminhos [ênfase] e a opção é minha",

O momento histórico que mais a marcou, além da morte do marido, foi disparado pelo que se vivia na época, o referendo sobre o desarmamento. Associando o tema (armas e poder) ao conflito árabe-israelense, a professora demonstrou como utiliza de maneira concreta o conhecimento histórico para orientar seu pensamento e tentar tomar uma posição. Ser professora de História torna-se, por fim, tanto um prazer quanto um tormento, pois as contradições precisam ser vividas e enfrentadas o tempo todo. Assim, sua utopia, sua concepção de professor e sua forma de sobrevivência na história acontecem pelas brechas que encontra no mundo contingencial. 
Ester trabalha com História há 15 anos em escola particular católica e, há poucos meses, na escola pública. De todos, foi a que mais falou da vida pessoal e da infância. De seu pai, diz, aprendeu a ética, o respeito, os valores religiosos e o amor pela profissão. As memórias de infância parecem ser fundamentais para suas formas atuais de atribuição de sentido.

Suas concepções sobre o professor de História e a educação ficam claras ao demonstrar a preocupação com a disciplina, com a organização da equipe pedagógica e com a crença no papel formador da escola, além da sua estabilidade identitária. Ester está sempre contando uma história, citando um exemplo, ao mesmo tempo que postula que conhecer os conteúdos da História é fundamental para que o aluno saiba agir em seu futuro. Para ela, a História é uma disciplina muito abrangente, na qual uma infinidade de conhecimentos, além do mero conteúdo, é disponibilizada. E nisso se reflete o papel do professor de História, de ir além do conteúdo e flertar com a moral, a ética, a ecologia, a política, a religião, etc., relacionando com o presente e abrindo perspectivas de futuro.

De forma um pouco mais abstrata do que Olga, a História continua sendo entendida por Ester como a grande orientadora da vida prática. Dentre os fatos históricos que mais a marcaram, destacou o filme $A$ força de um jovem, a partir do qual ela consegue visualizar o tipo de orientação para a vida de que precisam seus alunos. De certa forma, Ester descola o filme do contexto histórico e o subordina aos seus interrogantes e pilares de sentido mais urgentes no momento. Aí a história é subtraída de sua concretude, apesar do reconhecimento, acima, de que ela é importante como orientadora para o futuro.

Por fim, a visão de si mesma como professora é como o beija-flor que carrega água no bico e ajuda a apagar o fogo da floresta, sempre apoiada por Deus, que é seu "porto seguro" e deu a ela a missão de ajudar a conduzir os jovens.

\section{Formas de geração de sentido da consciência histórica}

De maneira geral, todos os professores demonstraram inserção na forma de geração de sentido tipo genética. Isso se constata de três formas: de acordo com a organização geral da narrativa, pelas respostas no terceiro questionário e pelas concepções de processo histórico descritas.

Todas as narrativas, quando tomadas em sua forma global, organizam-se de maneira genética. Verificam que as mudanças são ampliaçôes nas formas de vida, percebem mudanças e permanências no tempo com certa serenidade, procuram articular diferentes pontos de vista e perspectivas e percebem-se em 
relação conjuntural com os demais, deste e de outros tempos.

Nas respostas às narrativas que impunham tomadas de decisão, predominaram as afirmações de tipo genético, com exceção de três casos que serão debatidos em seguida. Quanto às concepções de processo histórico:

\section{Tabela I - Concepções de processo histórico}

\begin{tabular}{|c|c|}
\hline Professor & Processo histórico \\
\hline Ernesto & $\begin{array}{l}\text { Processo histórico é a dinâmica de transformação social através do tempo. } \\
\text { Seria a ação do homem sobre o resultado de uma realidade anterior, } \\
\text { gerando uma nova realidade, movimento que se estende pela vastidão do } \\
\text { tempo. }\end{array}$ \\
\hline André & Nada \\
\hline Sofia & $\begin{array}{l}\text { o processo histórico é algo que vai se formando, as conjunturas vão se } \\
\text { juntando, daí econômica, social, a politica, e em determinado momento o } \\
\text { processo está assim, pronto para ser deslanchado. [...] Eu consigo entender } \\
\text { assim, na conjuntura. }\end{array}$ \\
\hline Olga & $\begin{array}{l}\text { [...] a história é cíclica, que a história vem se repetindo, mas ela é cíclica e } \\
\text { ela vem se repetindo [...] nessa parte que nós estamos estudando, que é a } \\
\text { política, ela é cíclica aí. Agora, vamos pegar a mulher, a história da } \\
\text { mulher, ela não é cíclica. [...] Então eu vejo o processo histórico como um } \\
\text { processo em que algumas parcelas estão em espiral, algumas estão, lógico } \\
\text { que, crescendo bastante e às vezes parando, estagnando, voltando um } \\
\text { pouquinho [...] }\end{array}$ \\
\hline Ester & $\begin{array}{l}\text { É um elo: ontem, hoje e amanhã. Completo. Tem que construir, construir } \\
\text { o processo - é hoje. O ontem é o que você aprendeu, que está aqui ainda. } \\
\text { E o futuro, o amanhã, é uma incógnita ainda, mas que a gente espera que } \\
\text { seja melhor o construir a história. Ou não ser omisso... Que de omisso o } \\
\text { mundo está cheio. }\end{array}$ \\
\hline
\end{tabular}

Fonte: Pacievitch, 2008.

Nestas citações diretas, a maioria dos professores, com exceção de André, expressou uma forma de compreensão do processo histórico que pode ser caracterizada como genética, pois ele é visto a partir da ideia de inerência da mudança, persistência ou desenvolvimento nas formas de organização da vida (Rüsen, 2001). Nota-se, também, o sentido de inter-relação com outros pontos de vista (principalmente nas ideias de Sofia, de Ester e de Olga). A 
interligação com a forma crítica de atribuição de sentido aparece com a fala de Olga, que questiona a História masculina e política, levantando a possibilidade de estudar a História do ponto de vista feminino, que não é cíclico, em seu modo de ver. Talvez o silêncio ou a recusa de André a responder essas duas questôes também seja um indício de consciência histórica crítica, tendo em vista que se negou a compactuar com definições acadêmicas.

A questão da esperança aparece como pano de fundo, principalmente no discurso da professora Ester que, dentre todos, é a mais mobilizada para a questão religiosa, enquanto, em Ernesto e Olga, a crítica ao status quo e a ideia de transformação social surgem com mais força. Em Sofia, o processo histórico é visto em função de conjunturas diversas que praticamente independem da vontade humana.

A maneira como os professores constroem seu conceito de processo histórico tem uma relação forte com aquilo que chamamos de eixos ou indicadores de sentido (Heller, 1993; Rüsen, 2001), fundamentais para a formação da consciência histórica: as vivências (memórias individuais e coletivas, experiências profissionais), os conhecimentos adquiridos (acadêmicos e não acadêmicos), as indagaçôes advindas das mudanças pessoais e educacionais em geral.

No entanto, surgiram outros eixos de sentido que não estavam previstos na teoria de forma explícita: a construção de utopias e as crenças religiosas, que aparecem como pilares transcendentais de apoio à orientação na vida prática $\mathrm{e}$ na construção de identidades. As teorizações e as narrativas destes professores podem não ser uma correspondência exata do academicamente correto, mas são estratégias (bastante eficientes, pelo menos na maioria dos casos) para tornar coerentes e manipuláveis tanto os saberes adquiridos no processo de formação, quanto os saberes advindos das vivências temporais e transcendentais (como é o caso da utopia e da crença religiosa).

É possível destacar momentos em que as formas de geração de sentido da consciência histórica estão mais ou menos misturadas em cada narrativa. Destacam-se os pontos em que a forma exemplar apareceu, pois ela quase sempre vinha acompanhada de reflexôes sobre a História ensinada nas escolas. A importância que Ernesto atribui às mudanças orienta sua concepção de processo histórico, a forma como ele parece entender a narrativa histórica pode ser ligada à consciência histórica genética, corroborada tanto pela concepção de saber histórico, quanto por suas respostas no questionário fechado. Ernesto selecionou respostas genéticas nas questôes relativas ao conflito religião $\mathrm{X}$ ciência e às tradiçôes familiares, enquanto, na de caráter mais político, selecionou a alternativa crítica. Por outro lado, em suas afirmaçôes relativas à II Guerra e à Revolução de 30, são visíveis traços da História entendida como uma fornecedora de modelos de ação para o presente, ou seja, de consciência histórica exemplar. 
O modo de geração de sentido genético é predominante no depoimento, mas aparece articulado, principalmente, com o modo crítico e, depois, com o exemplar. A forma narrativa crítica permeia a construção argumentativa de Ernesto, principalmente porque ele está muito ligado ao que aprendeu na universidade; portanto, pouco confrontada com saberes advindos da experiência em sala de aula. Porém, observa-se a incorporação de um sentido crítico, ao expressar a necessidade de ação sobre os discursos acadêmicos.

André é o sujeito em que o modo exemplar está mais visível. As formas de atribuição de sentido podem ser caracterizadas como genéticas, levando em consideração apenas as respostas do Questionário 3, pois foram unânimes. No entanto, nas entrevistas, as remissões ao passado são escassas. Quando se trata de pensar sobre as implicações da História na vida atual, André tende a dirigir suas respostas para a função da História para seus alunos.

Quando fala das Cruzadas e do Bloqueio Continental, a História aparece cumprindo função didática - fornecedora de elementos para a compreensão do tempo presente, a partir do foco que Agnes Heller chama de analogia. André também caracteriza negativamente o período pós-64, pois foi um momento em que apenas "valia a História oficial". Da mesma forma, ele demonstra sua preferência por estudar em livros que não façam parte do círculo acadêmico. Assim, a História oficial era opressiva em 1964; analogicamente, continua sendo hoje e por isso deve ser negada ou substituída.

O foco da analogia está relacionado ao modo exemplar de produção de sentido histórico de Rüsen (2004), pois, neste, os fatos demonstram regras gerais de mudança temporal e ação humana, com o tempo ganhando o sentido de experiência. No caso de André, o modo exemplar acompanha de perto indícios de uma interpretação crítica do tempo.

Sofia também apresenta momentos em que o modo exemplar está presente. Quando fala sobre política, entende a importância das açôes pedagógicas na necessidade de criação do "homem novo", desprovido de certos vícios do presente. Falar sobre política inclui uma boa dose de desilusão, compensada pela crença num futuro diferente. $\mathrm{Na}$ segunda entrevista, ao explicar o que seria o "homem novo", a forma exemplar é evocada pelo papel educativo do saber histórico, embora ela não esteja nuclearmente presente nas estratégias de atribuição de sentido particulares da professora. Casos semelhantes podem ser observados em Ester.

Baseando-se em Agnes Heller (1993), é provável que os focos de sentido utilizados tenham alguma relação com a qualidade das identidades assumidas. Pode ser que a causalidade necessária expressa em pontos das várias narrativas (por exemplo, se o aluno estuda, ele terá um futuro melhor; se o professor é 
dedicado, as coisas acontecem) esteja ligada a um tipo de consciência histórica exemplar. Porém, não é este o teor geral da narrativa de Ester. Outro indício aparece quando fala de seu maior sonho: ver os ideais do Iluminismo, de liberdade, igualdade e fraternidade enfim realizados em sua plenitude. Nesse raciocínio, todo o contexto de elaboração, de pertença e as transformações pelas quais esses conceitos passaram são deixados de lado. Subtrai-se da história aquilo que é ideal, o sonho a ser alcançado, independentemente de qualquer obstáculo.

Olga apresenta poucos indícios do modo exemplar de produção de sentido histórico, mesmo quando fala do ensino de História. Não é apenas no conhecimento histórico (acadêmico ou não) que Olga encontra respostas, mas nas suas vivências. É a ligação do processo histórico coletivo com sua vida individual que permite formar o sentido da ação, pois só é possível compreender a situação de sua escola considerando-a no contexto educacional brasileiro. Histórias (desde memória histórica até memória individual) cujo desenvolvimento ajuda a construir o sentido de temporalidade são evocadas o tempo todo. Olga consegue inserir sua Pessoalidade na Conjuntividade por meio de estratégias genéticas e críticas, realizando o trabalho de conhecer o outro para conhecer a si própria.

E, no quesito ensino, predomina o conceito genético:

É um vai-e-vem, você vai lá na história, estuda a história, mas eu não deixo, antes de fechar o conteúdo, de puxar até os dias atuais aquela mesma questão. Ela acabou no meio do caminho, mas ela deu espaço pra uma outra coisa [...] daqui pra frente pra onde que a gente vai, o que é que a gente vai conquistar. Tem que achar algumas maneiras de viver! Quem tem que achar? Nós. Ou quem está vindo pela frente!

Em suma, é possível perceber a predominância da forma de geração de sentido genética, mesclada com a forma crítica. Olga utiliza os elementos da memória (como no caso do referendo sobre o desarmamento) como campos abertos para os acontecimentos futuros. Nesse sentido, é bem visível a História "oferecendo-lhe caminhos" e ajudando a formar estratégias de ação, porém sem impô-las. As formas de significação crítica aparecem mais quando ela fala da escola e do trabalho do professor. A organização e o cotidiano escolar são constantemente postos em julgamento. Segundo Rüsen (2004), a identidade na forma crítica dá-se pela negação de ordens obrigatórias, modelo em que Olga parcialmente se encaixa, porque ela aparece tanto como uma apaixonada pela História, quanto como uma contestadora da imposição dos pontos de vista ocidentais, masculinos e cristãos. 


\section{Religiosidade ou relações com o transcendental}

Ernesto disse ser ateu. André é católico não praticante, Sofia organiza novenas em sua casa, Olga diz que precisa acreditar em algo e Ester considera sua profissão como um chamado divino. Entre as diferentes formas de relação com o transcendente, apareceu nos depoimentos de Sofia e Ester uma intersecção entre conhecimento histórico, religião e visão política.

Essa ligação ficou clara quando as professoras responderam ao questionário fechado. Na pergunta 2, elas teriam de escolher uma posição em relação às pressōes dos pais e da comunidade diante das teorias da evolução X criacionismo na escola. Sofia escrevia sua resposta, enquanto comentava:

Eu acreditaria que você coloca aqui as questôes bíblicas como referências culturais e eu já colocaria assim ... [hesitação] ... o evolucionismo tem base cientifica. Mas tudo teve uma origem. [...] O evolucionismo tem bases cientificas, certamente. Mas tudo originou-se - é a minha conviç̧ão - numa força maior, criadora. Portanto as duas concepçôes casam-se. [... e. e Deus diz "Faça-se o homem" porque não poderia ser na teoria evolucionista o momento em que ele levanta sobre dois pés e descobre o fogo ou começa a articular as primeiras palavras?

Nessa resposta, religião, ciência, humano, divino e técnico estão organizados num todo coerente - com sua identificação como crente, como profissional cujo trabalho é despertar consciências e como cidadã que cumpre/cumpriu sua parte na história. Isso está, certamente, ligado com a utopia que carrega e seu sentido particular de Responsabilidade Planetária: "Eu tenho certeza de que eu fiz o possivel, dentro das minhas possibilidades".

Ester também optou por escrever sua própria resposta, reproduzida a seguir:

Explico que ciência e religiāo se completam, a Bíblia não explica a evolução, a ciência explica, a ciência não explica a origem de tudo a fé explica, a Bíblia coloca Deus como o Criador. Na evolução dos primatas [...] Deus deu ao homem a capacidade de raciocinar, inteligência e aos animais não [...].

Assim como Sofia, ela concilia ciência e fé de maneira que não entrem em conflito, pois História e religião católica são ambas importantes para a afirmação de sua identidade pessoal. $\mathrm{O}$ amor pela educação e a crença religiosa Ester aprendeu com o pai, e ambos permaneceram em suas experiências posteriores. Assim, o papel da religião - principalmente no que concerne ao contato íntimo com um "Deus inspirador" - aparece como importantíssimo foco de atri- 
buição de sentido. E essa postura não fica isolada de seu pensamento políticoutópico, como será apontado na próxima seção.

\section{Utopia e posicionamento político}

Os cinco professores, sem exceção, expressaram paixão pela História e pelo ensino (não necessariamente pelo processo educativo em seu aspecto político/ burocrático). Disseram que a História os faz ver o mundo de forma diferente. E demonstraram que seu raciocínio histórico ajuda na constituição de suas opções políticas (em alguns casos, junto com o sentimento religioso).

Ernesto escreveu muito sobre política, falou da importância do curso de História e da sua participação no movimento estudantil, além dos planos de inserir-se em outros movimentos, assim que possível. A política deve estar na escola, em sua opinião, inclusive nos currículos oficiais.

Ele deixa clara uma postura que é recorrente nos demais professores: a própria atividade profissional, a atuação em sala de aula, é uma forma de fazer política. Porém, a posição de André, no que se refere à política, é de desilusão, e ele evita nomear um lugar específico. Diz, citando Weber, que a política é um jogo de poder e não de trabalho pelo bem comum, sendo necessária uma mudança na consciência política de toda a nação - em que a disciplina da História tem seu papel a cumprir. Ele não participa de movimentos políticos na sua cidade, mas assume: "tento utilizar minhas aulas para motivar meus alunos".

Sofia entende a política ligada a conceitos universais a respeito do homem verdadeiro e digno, como no exemplo já visto a respeito da bomba atômica. É preciso criar nova "consciência de humanidade". A desilusão com o progresso, causada pelo horror da bomba atômica, aparece como elemento orientadorchave de suas concepçóes e de seus valores, por mais que eles pareçam atemporais, ou a-históricos. No entanto, a professora não deixa de vincular este posicionamento com suas convicções religiosas, como ela diz, pois só a matéria deixa o homem "vazio".

$\mathrm{Na}$ argumentação geral da professora, a ligação do transcendente religioso com a ideia de "humanidade" foi a maneira encontrada para dar sentido e significado à profissão, ao mundo e ao tempo. As histórias evocadas mobilizam escolhas políticas e identitárias, principalmente sobre o papel do professor de História. Apesar de Sofia ser uma entusiasta de movimentos como o Focolare, não participa ativamente de nenhum - exceto o trabalho como professora, em suas próprias palavras.

Ester, quando questionada sobre seu posicionamento político, diz não ser nem de direita nem esquerda: mas é adepta da educação digna, ética, com princípios advindos da sua religiosidade. Ela se esforça para deixar religião e política em estratos próximos, significativos e coerentes: 
Não tem como você ser extremamente radical à esquerda, e esquecer que todo ser humano foi criado por Deus e que tem os mesmos direitos e os mesmos princípios. [...] Deus criou o homem pra ser digno, pra viver em amor [...]. Ser direita ao extremo, que só conquista, explora, explora, explora, pra mim também não é. Mas hoje o que é que a gente precisa: hoje a gente precisa tirar esse povo que morre de fome! [...] Mas eu penso que esse lado tem que ser hoje resgatado. E[...] a única forma de resgatar isso, pela politica, é a educação [...] Então se o governo não tirar um percentual maior do investimento na educação, a nossa crise política não vai ser sanada. [...] Porque não há investimento e não há dignidade de envolvimento na educação. [...] Porque o que éo professor: ele passa aquilo que tem! Eu passo moral, eu passo política, eu passo religiāo, eu passo Deus, eu passo conteúdo, se eu tenho! [ênfase]

Para Olga, os movimentos sociais e a participação política são considerados muito importantes para a sua formação como professora de História. São eles que trazem as vivências. Cidadania só se ensina se o professor sabe ser cidadão e carrega sua bandeira. Olga procura articular de forma coerente a utopia que defende para a escola e a sociedade com a realidade que encontra na escola:

Todos os professores deveriam carregar uma bandeira e deveriam se identificar com o conhecimento. [...] E também você não consegue dentro de um ambiente escolar desse aqui dar liberdade pra aluno. Você precisa ser um pouco ditador dentro de sala de aula, então eu me questiono um pouco [...] Eles entram no portão, fecham os portôes, é como se fosse um presídio [...] Cada um tem a sua cela, $e$ dentro da sua cela cada um tem a sua solitária que é a sua carteira [...] aonde que muda de carcereiro a cada 45, 50 minutos. Evocê joga lá dentro português, joga lá dentro matemática, joga lá dentro ciências, e joga lá dentro história [... então vocêpensa "gente, que tortura!"

Dentro da sala de aula, o professor precisa focalizar o conhecimento e o poder que ele tem nas escolhas que os jovens devem fazer. Mas ser professor não é fazer política.

A que se devem essas diferenças? A princípio, parece que a vida politicamente ativa fora da escola não cria necessidade de justificar açóes políticas a partir da vida profissional. Separam-se as coisas. Olga percebe-se como uma professora bem informada, que compreende a vida e as necessidades de seus alunos, mas atua dentro do contexto e das limitações da vida escolar. Em seu ponto de vista, não adianta pedir da escola algo que ela não pode oferecer.

Os outros professores discordam. A partir do momento em que ajudam os alunos a utilizar "seu poder pessoal" (conforme Ernesto), realiza-se a própria 
função política. Transmitir conteúdos e motivar para a ação - ambos são papéis do professor de História. No entanto, fica um vácuo. No momento de defender seus próprios interesses como classe, os professores partem para a ação? Consideram-se agentes políticos, ao criticar e propor mudanças curriculares, de carreira? Interrogaçôes que ainda estão por responder.

Apresentados os professores entrevistados na primeira fase da pesquisa, percebe-se um jogo entre a heterogeneidade e a homogeneidade em seus depoimentos. São cinco professores com perfis distintos entre si. Por outro lado, a maioria deles acredita que o fato de trabalharem como professores de História significa algo maior do que simplesmente repassar conteúdos, registrar presenças e aplicar avaliaçóes. Ser professor de História está ligado ao seu projeto de vida e de sociedade, incluindo aí crenças, valores e utopias. A concepção de cada um sobre processo histórico não se desvincula da forma como atribuem sentido às suas narrativas pessoais, nem o conceito de saber histórico se desliga de suas utopias, principalmente no que concerne ao papel atribuído ao professor de História.

Do grande universo de opções de análise que se oferece nas narrativas destes professores, chamaram a atenção três unidades de sentido que, embora não apareçam com a mesma força nos cinco depoentes, escapam do sistema previsto pela teoria da consciência histórica. São os aspectos da utopia, da religiosidade e do conhecimento histórico. Vários deles expressaram um discurso que pode ser vinculado, grosso modo, a utopias de caráter progressista - Ernesto, com o professor onipresente; Olga, questionando o status quo educacional; e Ester, com o desejo de ver um mundo mais justo - e, ao mesmo tempo, negaram (com a exceção de Olga) filiação a algum partido político.

\section{Considerações finais}

A pesquisa permite argumentar que os professores de História não se assumem nem como sacerdotes, nem como guerrilheiros. Os professores participantes não correspondem à representação corrente do professor abnegado, cujos passos são guiados por um ideal transcendental que exige sacrifícios, gerando a ideia de que a recompensa virá em um outro tempo. Não são os revolucionários engajados, críticos, contestadores e militantes que creem na transformação radical da sociedade, porque o movimento da história apontaria para isso. As identidades mostraram-se complexas, rechaçando ou admitindo estereótipos, mas sempre na busca de reconstrução e ressignificação.

Religiosidade, mobilização política e paixão pelo conhecimento histórico não se apresentaram como estruturas cognitivas ou emocionais inconciliáveis, mas coerentes com seus eixos de sentido. 
Concepções religiosas e utopias políticas, por mais que obedeçam a estruturas temporais, teleológicas e transcendentes, encaixam-se dentro da forma de atribuição de sentido dominante na narrativa. Por essa razão, os professores sentiram-se à vontade para afirmar que tanto suas posições políticas quanto suas posições religiosas influenciam em seus ideais e práticas escolares e extraescolares.

O saber histórico é um fator de conhecimento que, para os professores, reflete-se em sua vida de maneira global. Da mesma forma, religiosidade, filosofias de vida e sonhos de um mundo melhor permeiam concepções do processo histórico e do papel do profissional da História. O sentido da intelectualidade do professor de História preserva-se na incorporação crítica de discussōes epistemológicas e historiográficas, expressas nos conceitos de neutralidade e de processo histórico, assim como nas evocações de determinados conteúdos.

As identidades dos professores de História são resultados de construçôes estáveis (na maioria dos casos). Mostram que as histórias de vida, as memórias como alunos, o conhecimento acadêmico sobre a história, as utopias políticas e a relação com o transcendente são pilares de sentido que se organizam numa narrativa de caráter genético, quase sempre voltada para a realização da "Responsabilidade Planetária". Assim, o processo de consciência histórica mostrouse importante para pensar uma das formas de constituição docente: a partir da construção de saberes e identidades dos professores de História.

\section{Referências bibliográficas}

ANGVIK, Magne; BORRIES, Bodo von (Ed.) Youth and History: a comparative European survey on historical consciousness and political attitudes among adolescents. Hambourg: Edition Körber-Stiftung, 1997.

BAUMAN, Z. Identidade: entrevista a Benedetto Vecchi. Tradução de Carlos Alberto Medeiros. Rio de Janeiro: Jorge Zahar, 2005.

FONSECA, Selva G. Ser professor no Brasil. História oral de vida. 2. ed. Campinas: Papirus, 2003.

GOODSON, I. Dar voz ao professor: as histórias de vida dos professores e seu desenvolvimento profissional. In: NÓVOA, A. Vidas de professores. 2. ed. Porto: Codex Porto, 1995.

HELLER, A. Uma teoria da História. Tradução de Dílson B. de F. Ferreira Lima. Rio de Janeiro: Civilização Brasileira, 1993.

HUBERMAN, M. O ciclo de vida profissional dos professores. In: NÓVOA, A. Vidas de professores. 2. ed. Porto: Codex Porto, 1995.

KÜNZLE, Maria Rosa Chaves. O ensino de História e o conceito de nação: um instrumento de pesquisa. Dissertação (Mestrado) — PPGE-UFPR, Curitiba, 2003. 
KUSNICK, Marcos R. A filosofia cotidiana da História: uma contribuição para a didática da História. Dissertação (Mestrado) — PPGE-UEPG, Ponta Grossa, 2008.

MEIHY, J. C. S. Manual de história oral. São Paulo: Loyola, 1996.

PORTELLI, A. O que faz a história oral diferente. Projeto História, São Paulo, n. 14, p. 25-39, fev. 1997.

RÜSEN, Jörn. El desarrollo de la competencia narrativa en el aprendizaje histórico. Una hipótesis ontogenética relativa a la conciencia moral. Propuesta Educativa, Buenos Aires, n. 7, p. 27-36, 1992.

RÜSEN, Jörn. Razão histórica. Teoria da História: os fundamentos da ciência histórica. Brasília: Editora da UnB, 2001.

RÜSEN, Jörn. Historical consciousness: narrative structure, moral function and ontogenetic development. In: SEIXAS, Peter. (Ed.) Theorizing historical consciousness. Toronto: UTP, 2004. p. 63-85.

SCHMIDT, Maria Auxiliadora; GARCIA, Tânia Braga. A formação da consciência histórica de alunos e professores e o cotidiano em aulas de História. Cadernos CEDES, Campinas, SP, v. 25, n. 67, p. 297-308, set./dez. 2005.

ZAVALA, Ana; SCOTTI, Madalena. Historias de la enseñanza de historia. Relatos que son ... Teorías. Montevideo: Centro Latinoamericano de Economía Humana, 2005.

Recebido em 14 de abril de 2009 e aprovado em 10 de fevereiro de 2010. 